Atmos. Chem. Phys. Discuss., 2, 1979-2001, 2002 www.atmos-chem-phys.org/acpd/2/1979/

(C) European Geosciences Union 2002

\title{
Modelling studies of wind field on urban environment
}

\section{K. Radics ${ }^{1,2}$, J. Bartholy ${ }^{2}$, and R. Pongrácz ${ }^{2}$}

${ }^{1}$ Meteological Service of the Hungarian Defence Forces, Budapest, Hungary

${ }^{2}$ Department of Meteorology, Eötvös Loránd University, Budapest, Hungary

Received: 13 August 2002 - Accepted: 25 October 2002 - Published: 11 November 2002

Correspondence to: K. Radics (nelly@ nimbus.elte.hu)

\section{ACPD}

2, 1979-2001, 2002

\section{Modelling studies of} wind field

K. Radics et al.

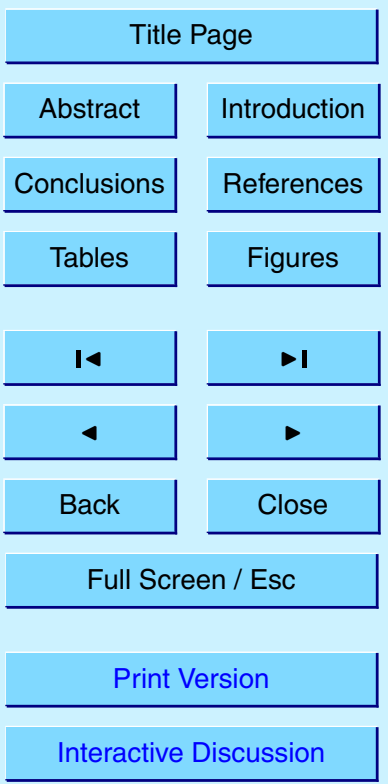

(C) EGU 2002 


\section{Abstract}

Increasing load of air pollution in urban environment emphasises the need for detailed evaluation of wind characteristics that significantly affect the air quality of urban areas, especially, in large agglomerations. This paper includes analysis of urban wind cli5 matology and estimation of wind profiles based on measurements of the new urban climate station located at the Eötvös University, observations of the meteorological station network of the Budapest agglomeration area, and multi-level wind measurements near Hegyhátsál. Furthermore, wind field modelling (using the WAsP linear spectral wind flow model) is presented over selected representative complex areas that demonstrates strong dependence between wind, height, topography, and roughness.

\section{Introduction}

Urban areas and inhabitants of cities tend to increase; nowadays about half of the world total population live in urban settlements. The highest continental population density occurs in Europe where out of 750 million people 500 million live in large cities (Fenger et al., 1998). This large number of dwellers and the socio-economic conditions produce high industrial activity and modify urban air quality. Budapest (capital of Hungary, located in Central Europe) is one of the 21 major cities of Europe, with over 1 million inhabitants.

Surface temperature has increased by almost $0.1^{\circ} \mathrm{C}$ per decade on the average in Budapest this century. Several network systems were established in the last 40 years to observe and record these changes (Mika, 1999). Private companies, health control authorities and the Hungarian Meteorological Service started and stopped to maintain various stations by governmental orders. Therefore, lengths of the time series and data quality are not always the best. During the last few years the measuring system was reorganised into a new network and according to the present socio-economical needs some new stations were added to the existing ones. One of them was installed
ACPD

2, 1979-2001, 2002

Modelling studies of wind field

K. Radics et al.

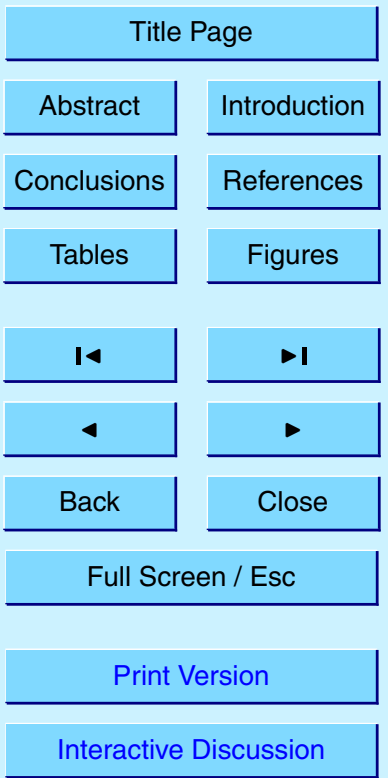

(C) EGU 2002 
at the Eötvös University in October 1999 (Bartholy and Pongrácz, 2000). The new urban climate station is located at the western riverside of the Danube, north to the Csepel Island. The present paper is focused on the analysis of urban wind climate characteristics and the evaluation of wind field modelling over selected complex areas.

Mesoscale wind models provide an excellent tool to investigate wind field modifications of urban environments. In the frame of a research project a linear spectral wind model WAsP has been applied and tested. The aim of this research was to analyse the applicability of the model on different terrain and surface conditions. Wind measuring field experiments have been performed to determine the possible wind field modifica10 tion of urban environments. Wind profile was analysed using multilevel wind measurements (from $10 \mathrm{~m}$ to $115 \mathrm{~m}$ ) at the Hegyhátsál area. Significant differences were found in wind speed frequency distributions of vertical levels during the year. Further analysis has been carried out over selected representative areas by estimating horizontal and vertical cross sections of wind fields.

\section{Urban wind climate}

Before starting the detailed analysis, as a first step, the Budapest metropolitan area have been classified into five major categories (Fig. 1), which have different characteristics considering absorption and radiation of heat and energy, and emission of pollutants. Highways and main roads are also indicated on the structural map of Budapest

since they act as an important source of air pollution through transportation and traffic. This map of city structure can serve as the important input of complex models to predict heat transport and pollution transmission processes.

Co-operation of the Department of Meteorology and the Hungarian Meteorological Service (HMS) resulted in installing a new urban climate station at the Eötvös University 25

(n)
quality control the first month was considered as a testing period. Data set available for analysis begins on 1st December 1999.

ACPD

2, 1979-2001, 2002

\section{Modelling studies of} wind field

K. Radics et al.

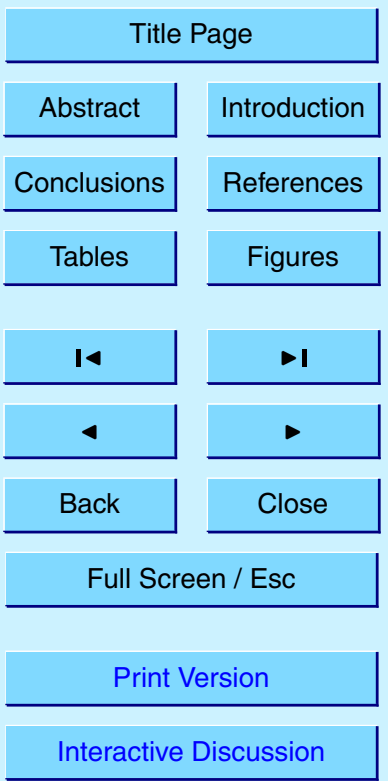

(C) EGU 2002 
The QLC 50 automated meteorological observer (Fig. 2) at the climate station at the Eötvös University is maintained by the HMS and data quality is guaranteed by regular calibrations realised by experts of the HMS twice a year. The synoptic automatic measurement device operates without human supervision and it is equipped with several 5 sensors which provide temperature measurements at $2 \mathrm{~m}$, at the surface, 5, 10, and $20 \mathrm{~cm}$ below the surface, relative humidity values, precipitation amounts, global radiance values, wind speed, wind gust, and wind direction measurements at $41 \mathrm{~m}$ above the surface (Table 1). Being an automated station, all the measurements are continuous, however, the actual and mean values are recorded at every $10 \mathrm{~min}$ (Bartholy et al., 10 2001). Special wind climate occurs at the location of the climate station at the Eötvös University since the Buda and the Pilis Hills functions as barriers for the air motions coming generally from north-western direction at this region. The empirical distributions of wind directions measured at that climate station show higher dominance of SW and $\mathrm{N}$ winds (Fig. 2) both in December and June. The relative frequencies of 15 these wind directions are around $22-28 \%$ that is noteworthy considering the average wind direction frequencies.

Figure 3 represents the general distribution of relative frequencies of wind direction based on 30 year observations (1961-1990) in Budapest-Lörinc meteorological station (HMS, 2002). In the Carpathian Basin as well as in the large Hungarian cities northwestern wind dominates the horizontal air mass transport processes near the surface, although wind climate of the metropolitan area on a finer scale shows a much more complex distribution.

Other data sets covering earlier periods were analysed and compared for providing fine resolution spatial wind structure of the Budapest metropolitan area (Dezsö, 2000). Hourly measurements (for more than seven years) used in the analysis were observed and recorded in a network that consists of 23 stations representing the city and its agglomeration. These observing stations can be classified according to their locations. They are located in the downtown (4 stations), in the residential (6 stations) and the industrial (6 stations) districts, or in suburb villages (7 stations). Eight rep-
ACPD

2, 1979-2001, 2002

Modelling studies of wind field

K. Radics et al.

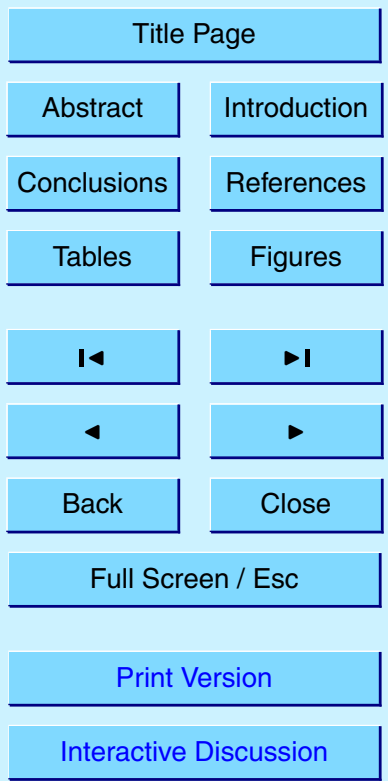

(C) EGU 2002 
resentative stations have been selected for presenting dominant modifications of the airflow patterns by orographical and built-up areas in Budapest (Fig. 4). Table 2 gives additional information about the eight stations, namely, their names, orographical status, and built-up category. The valley effect can be recognised in case of station 2 since 5 the dominant NW wind is determined by the direction of the valley. In dense built-up areas the geographical position of avenues, broad streets, and boulevards explains the dominant $\mathrm{N}$ and NNE wind at station 7 and 8, respectively.

\section{Wind profile}

Collaborating with the AEROCARB EU-5 framework project (Haszpra et al., 2001) we 10 had the opportunity to carry out wind profile measurements near Hegyhátsál, at a site of the north-western part of Hungary $\left(46.96^{\circ} \mathrm{N}, 16.65^{\circ} \mathrm{E}\right)$. Wind speed and wind direction have been observed at four levels from the end of September 1994 (Bartholy and Radics, 2001) on a $117 \mathrm{~m}$ tall TV and radio transmitter tower. The measuring station is located on $248 \mathrm{~m}$ above sea level. As shown in Fig. 5, the lower part of the 15 tower $(56 \mathrm{~m})$ is a $7.75 \mathrm{~m}$ diameter cylinder where measurements are recorded at $48 \mathrm{~m}$ height in both south and north direction. On the upper cylindrical part (1.82 $\mathrm{m}$ diameter) measurements are performed at 82 and $115 \mathrm{~m}$ height in north direction.

First, data set of the lowest measuring point (near surface) was analysed. The instrument is placed at $10 \mathrm{~m}$ above ground and $70 \mathrm{~m}$ away from the tower with the intention 20 to exclude as much as possible shelter effects of the tower. The well-known annual cycle of wind speed can be recognised in the observed data. April is the windiest month in Hegyhátsál area and October is the least windy month of the year, as the Hungarian wind climate can be characterised in general. Therefore, relative wind speed frequencies of these months are presented in Fig. 6. The first two columns represent the relative frequencies of wind calm and very small wind (less than $1 \mathrm{~m} \mathrm{~s}^{-1}$ ) periods, which are relatively low compared to some other regions of Hungary. Certainly, those periods appear much more frequently in October $(9.3 \%, 26.8 \%)$ than in April $(5.0 \%$,
ACPD

2, 1979-2001, 2002

Modelling studies of wind field

K. Radics et al.

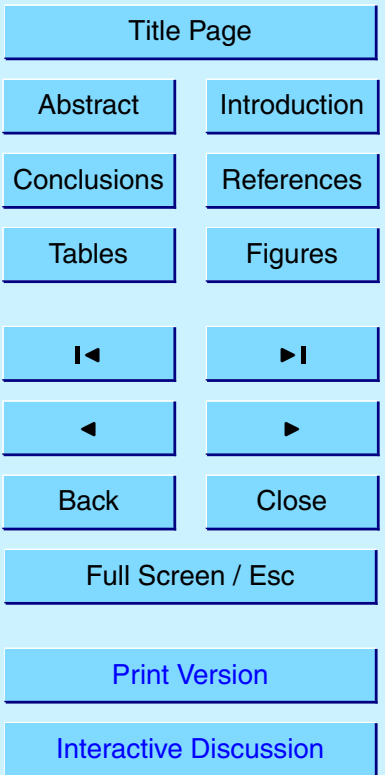

(C) EGU 2002 
$18.5 \%)$. In both months the most frequent wind speed values are in the $0-4 \mathrm{~m} \mathrm{~s}^{-1}$ interval. However, wind speed values above the average in April occur more often than in October.

Multilevel wind speed measuring experiments on towers are suitable to estimate the 5 vertical profiles of wind speed. Although our data set includes errors coming from the shelter and wind field perturbation effects of the specially shaped tower, detailed profile analysis and profile fitting can provide appropriate information about the vertical structure of the flow.

Six-year-long (1995-2000) database measured at four levels was analysed. Classification of wind speed values is based on the near surface time series (observed at $10 \mathrm{~m}$ ). Periods with wind speed less than $1 \mathrm{~m} \mathrm{~s}^{-1}$ were excluded from the analysis having no significant effect in air movement and vertical mixing (calm periods in April is $5.0 \%$, and $9.3 \%$ in October). After a detailed analysis tercile values of wind speed time series in April near the surface $\left(2.5 \mathrm{~m} \mathrm{~s}^{-1}\right.$ and $\left.4 \mathrm{~m} \mathrm{~s}^{-1}\right)$ have performed the best statistical tool to classify vertical wind profiles. Ranked data were divided into three groups with equal number of observations (33.3\% of data in each group). Figure 7 shows the frequency distributions of observations from the higher measuring levels $(48,82$ and $115 \mathrm{~m}$ ) based on the near surface wind speed classification described above. Also, the smoothed curves of the distributions are indicated on the figure (where the running 20 mean technique were applied for all consecutive wind speed classes). In order to compare the selected two months, the same threshold values (terciles of April) were used for October leading to an asymmetric distribution (46.9\%, $31.8 \%$ and $21.3 \%$, respectively). Figure 8 represents the relative frequencies of the above-defined categories in case of October.

25 In spite of the unequal distribution of the groups of October data, relative frequencies remain smaller than in case of April. However, large differences in wind climate conditions cannot be observed between April and October at higher levels. As height and wind speed increase the range of wind speed frequencies is getting larger resulting in larger errors in wind profile estimation.
ACPD

2, 1979-2001, 2002

Modelling studies of wind field

K. Radics et al.

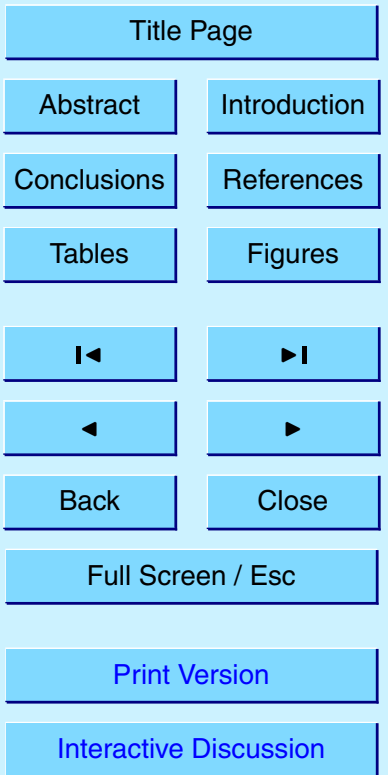

(C) EGU 2002 


\section{Wind field estimations}

Speed, direction, and turbulence of wind is modified by changes in surface properties. There are essentially four characteristics of the surface whose variations cause changes in wind field near the ground: surface roughness, topography, shelter from 5 nearby buildings, obstacles, and thermal and moisture properties of the surface. When air flows over different surfaces, each have specific modification effects on the flow. Generally, most changes in properties of urban surface are fairly abrupt. In order to analyse urban wind fields meteorological and climatological impacts of the urbanisation must be investigated. Comparing rural and urban environments, surface characterishave different significance. For example: seasonal variations have less influence on urban climate; houses, buildings causes considerable wind field modifications as well (street canal effects, tower building turbulence, etc.).

Before estimating the modification effects of the general flow, it is necessary to map the spatially continuous wind fields. Such maps can be obtained solely by using wind 15 models. The WAsP model (Mortensen et al., 1993) developed at Risø National Laboratory, Roskilde, Denmark has been selected for this reason. It is a linear spectral model for near neutral boundary layer flow over complex terrain. The model can be used to analyse raw time series and estimate the wind climate at any site using digitised topographical, roughness, and shelter maps.

20 In order to verify the WAsP model for selected regions of Hungary, input data measured at Hegyhátsál at $10 \mathrm{~m}$ height have been used to model the wind field over the complex terrain of $41 \mathrm{~km} \times 41 \mathrm{~km}$ area (Radics and Bartholy, 2002a). The topography has been included in WAsP as a height-contour map using $25 \mathrm{~m}$ isolines. Roughness length has been set to $1 \mathrm{~m}, 0.5 \mathrm{~m}$, and $0.1 \mathrm{~m}$ for forests and cities, villages and orchards, and shrublands or grasslands, respectively. In case of water bodies, $0.001 \mathrm{~m}$ has been chosen. Effects of every obstacle near the station have been taken into consideration. Preliminary results of comparing measured wind data to simulated values suggest that the WAsP model provides reasonable output fields in case of low variabil-
ACPD

2, 1979-2001, 2002

Modelling studies of wind field

K. Radics et al.

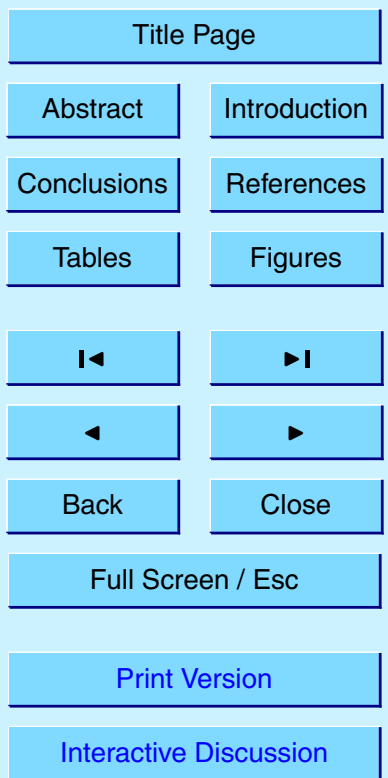

(C) EGU 2002 
ity in orography of Hungary (Bartholy and Radics, 2001). Therefore, it is possible to extrapolate wind data of Hegyhátsál simulating mean flow over the surroundings.

After including the orographical characteristics into the WAsP model measured wind data were extrapolated horizontally and vertically. On Fig. 9 a case study for the

5 Hegyhátsál area is presented. First, mean wind speed field was simulated for a $41 \mathrm{~km}$ $\times 41 \mathrm{~km}$ area around the measuring site at 10,20 , and $30 \mathrm{~m}$ height. The model run was based on a fine resolution digital terrain model (DTM 1000) and on the measured wind speed at $10 \mathrm{~m}$ height (Fig. 9). The simulated mean wind speed values, as well as, the topography are in good agreement with the structure of the measured data (Radics 10 and Bartholy, 2002b). Consequently, the case study demonstrates strong dependence on height and topography.

Figures 10 and 11 presents the vertical cross-sections (longitudinal and latitudinal, respectively) of average wind fields resulted from simulations using the WAsP model. On both diagrams the vertical structure of wind speed fields in Hegyhátsál area can 15 be recognised through the run of the 3,4 , and $5 \mathrm{~m} \mathrm{~s}^{-1}$ isolines. This kind of figures can provide valuable information and a better view of the three-dimensional wind field structure over complex terrain and around artificial obstacles, which can support urban planning in the future in Hungary.

\section{Conclusions}

20 Urban effects on local climatic conditions were analysed with special consideration of the wind structure for the Budapest metropolitan area. Measurements of the new urban climate station installed at Eötvös University were described. Wind direction analysis have been carried out based on the observations of the urban wind measuring network selected those parts of the city where the strongest air pollution effects may occur.

Wind profile measurements and data analyses were carried out on Hegyhátsál measuring tower, where multilevel wind speed time series are available from the 1994-2000 period. Selecting the windiest (April) and the least windy (October) months of the year,

\section{Modelling studies of wind field}

K. Radics et al.

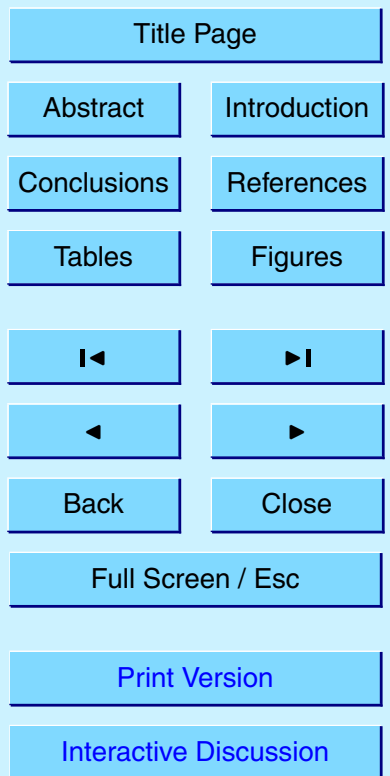


wind speed frequency distributions was analysed. Case classification was based on truncated tercile values of near surface $(10 \mathrm{~m})$ data of April. Using the same terciles for October, leading to an asymmetric distribution of group members, relative frequencies remain smaller than in April. Larger differences can be observed near the surface that 5 seems to become smaller in higher levels.

Horizontal and vertical cross-sections of wind fields resulted from WAsP model simulations were analysed. The demonstrated wind speed isolines can provide useful tools for mapping the main characteristics of the local flow that support optimal urban planning.

10 Acknowledgement. The authors wish to thank the MOWIE project (Department of Earth Sciences - Meteorology, Uppsala University, Sweden, JOR3CT980254) for the application of the WAsP model. We are very grateful to L. Haszpra (Hungarian Meteorological Service) and Z. Barcza (Eötvös University, Department of Meteorology) for the wind profile data from Hegyhátsál, to T. Weidinger (Eötvös University, Department of Meteorology) for the digital ter15 rain model. Furthermore, authors thank to D. Szepesi and Zs. Dezsö for their kindness in providing the wind data and results of their analysis.

Research leading to this paper has been supported by the Hungarian National Science Research Foundation under grants T23811, T26629, T34867 and T38423, and the National research Development Program under grant NKFP-3A/0006/2002, also, by the AEROCARB EU-5

20 framework project (EVK2-CT-1999-00013).

Furthermore, support of the Bolyai János Research Fellowship of the Hungarian Academy of Sciences is appreciated.

\section{References}

Bartholy, J. and Pongrácz R.: Estimation of the urban heat island effect for Budapest, Proceedings of the 3rd European Conference on Applied Climatology, (Eds) Falchi, M. A. and Zorini, A. O., 2000.
ACPD

2, 1979-2001, 2002

Modelling studies of wind field

K. Radics et al.

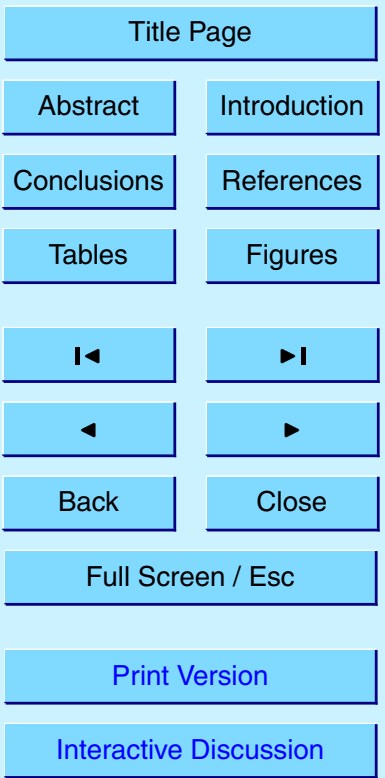

(C) EGU 2002 
Bartholy, J., Pongrácz, R., Mészáros, R., Kern, A., Dezso, Zs., and Barcza Z.: Urban meteorological effects estimated for the Budapest metropolitan area, Geophysical Research Abstracts, 3, GRA3 4591, 2001.

Bartholy, J. and Radics, K.: Selected characteristics of wind climate and the potential use of wind energy in Hungary. Part I, Idojárás 105, 109-126, 2001.

Dezsö, Zs.: Potential environmental effects of large cities on wind structure based on wind observations in Budapest, Working paper for Students' Conference on Environmental Science, Debrecen, 2000.

Fenger, J., Hertel, O., and Palmgren, F.: Urban air pollution - European aspects, Kluwer Academic, Dordrecht, 1998.

Haszpra, L., Barcza, Z., Bakwin, P. S., Berger, B. W., Davis, K. J., and Weidinger, T.: Measuring system for the long-term monitoring of biosphere/atmosphere exchange of carbon dioxide, J. Geophys. Res., 106, D3, 3057-3070, 2001.

Hungarian Meteorological Service: Climate Atlas of Hungary, Budapest, 2002.

Mika, J.: On connection of the heat island effect of cities and the global climate changes, 1st Workshop on Urban Climatology, Climatological and Agrometeorological Papers No. 6. , Hungarian Meteorological Service, Budapest, 69-80, 1999.

Mortensen, N. G., Landberg, L., Troen, I., and Petersen, E. L.: Wind Atlas Analysis and Application Program, Risø National Laboratory, Roskilde, 1993.

20 Radics, K. and Bartholy, J.: Selected characteristics of wind climate and the potential use of wind energy in Hungary, Part II, Idojárás 106, 59-74, 2002a.

Radics, K. and Bartholy, J.: Estimation of climate effects of land use changes with simple wind models, Physics and Chemistry of the Earth (in press), 2002b.

Modelling studies of wind field

K. Radics et al.

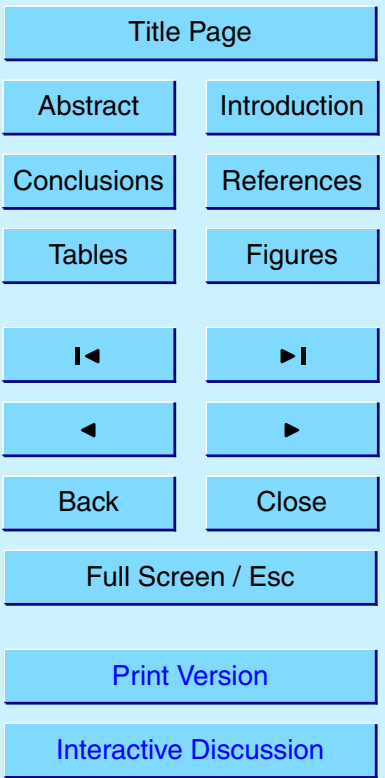

(C) EGU 2002 


\section{ACPD}

2, 1979-2001, 2002

Modelling studies of wind field

Table 1. Instrumentation summary of the urban climate station at the Eötvös Loránd University, Budapest

\begin{tabular}{lcc}
\hline Measured parameter & Instrument & $\begin{array}{c}\text { Measuring height }(\mathrm{m}) \\
\text { relative to the surface }\end{array}$ \\
\hline soil temperature & Vaisala, DTS12G & $-0.05 \mathrm{~m}$ \\
& & $-0.10 \mathrm{~m}$ \\
surface temperature & Vaisala, DTR15 & $-0.20 \mathrm{~m}$ \\
air temperature & Vaisala, HMP35D & $0 \mathrm{~m}$ \\
relative humidity & Vaisala, HMP35D & $2 \mathrm{~m}$ \\
precipitation & Lambrecht - rain gauge & $36 \mathrm{~m}$ \\
global radiance & Vaisala, CM3 & $36 \mathrm{~m}$ \\
wind speed & Vaisala, WAA15A & $41 \mathrm{~m}$ \\
wind gust & Vaisala, WAA15A & $41 \mathrm{~m}$ \\
wind direction & Vaisala, WAV15A & $41 \mathrm{~m}$ \\
\hline
\end{tabular}

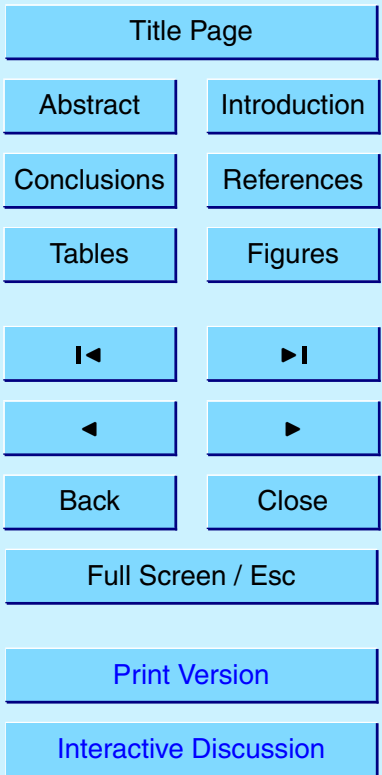

(C) EGU 2002 


\section{ACPD}

2, 1979-2001, 2002

Modelling studies of wind field

Table 2. Description of the wind measuring stations (measuring heights at $10 \mathrm{~m}$ ) in Budapest mapped on Fig. 4

\begin{tabular}{|c|c|c|c|}
\hline No. & Name & Topography & Built-up category \\
\hline 1. & Obuda & foothills, valley & family houses \\
\hline 2. & Hung. Met. Service & foothills, valley & $\begin{array}{l}\text { residential area, } \\
\text { multi-story houses }\end{array}$ \\
\hline 3. & Astronomical Obs. & top of hill & forest \\
\hline 4. & Gellérthegy - Citadella & top of hill, near the river & park with trees \\
\hline 5. & Budatétény & flat & $\begin{array}{l}\text { family houses with gardens, } \\
\text { agricultural area, forest }\end{array}$ \\
\hline 6. & Res. Inst. of Atmos. Phys. & flat & $\begin{array}{l}\text { family houses with gardens, } \\
\text { industrial area }\end{array}$ \\
\hline 7. & Nagyvárad Square & flat & $\begin{array}{l}\text { multi-story houses, main roads } \\
\text { crossing, large traffic }\end{array}$ \\
\hline 8. & Madách Square & flat & $\begin{array}{l}\text { multi-story houses, business } \\
\text { district, large traffic }\end{array}$ \\
\hline
\end{tabular}

K. Radics et al.

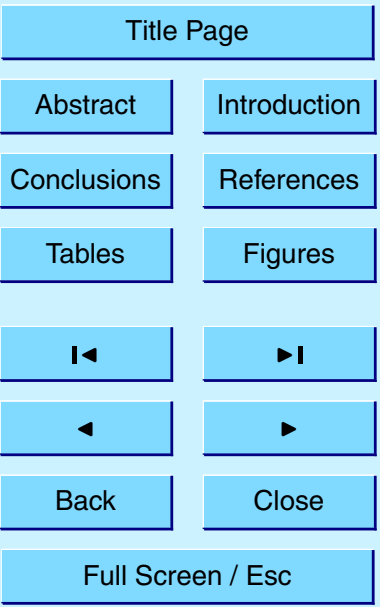

Print Version

Interactive Discussion

(C) EGU 2002 


\section{ACPD}

2, 1979-2001, 2002

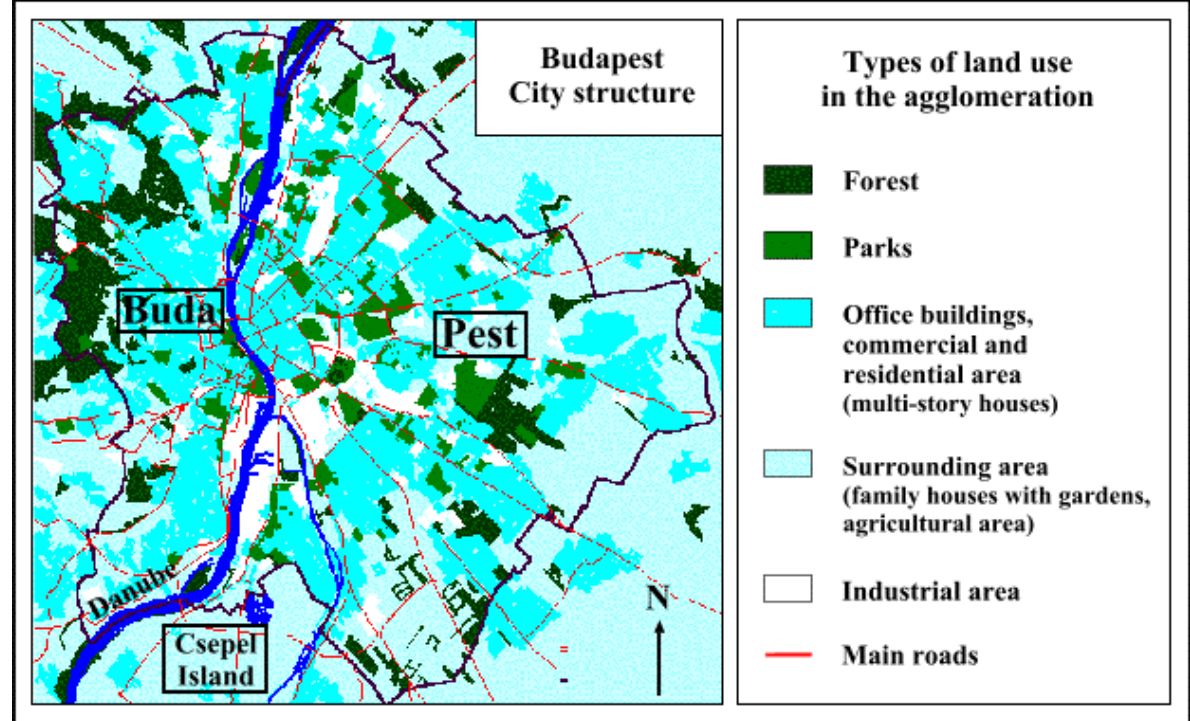

\section{Modelling studies of wind field}

K. Radics et al.

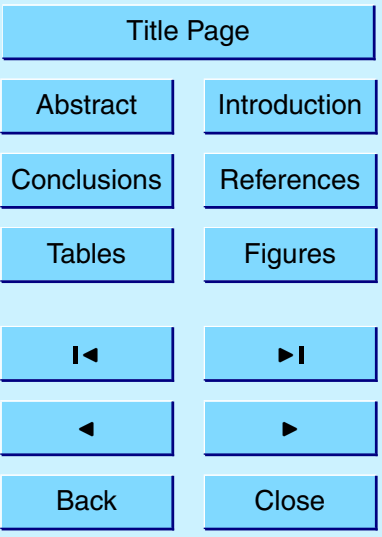

Full Screen / Esc

Fig. 1. Structural map of land use classes in the Budapest metropolitan area.

Print Version

Interactive Discussion

(C) EGU 2002 


\section{ACPD}

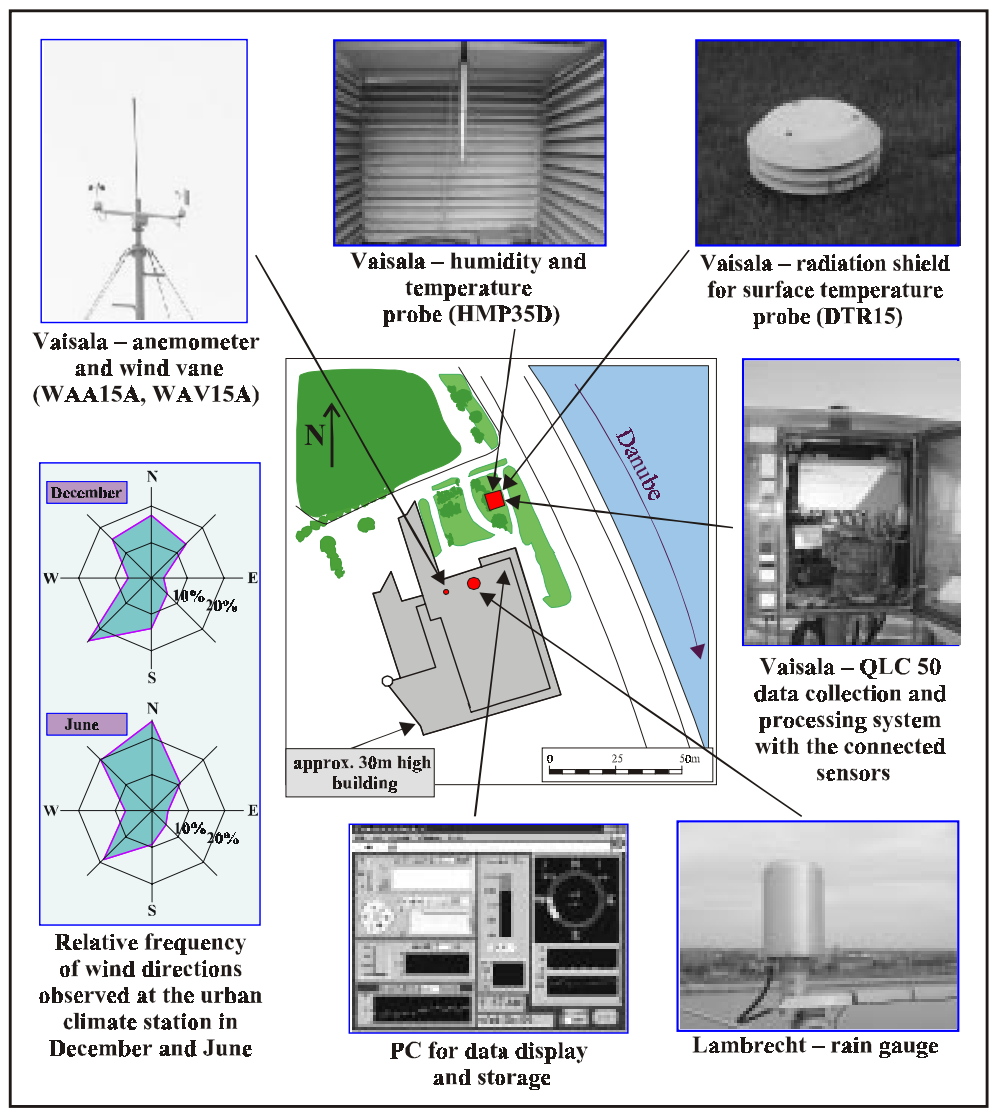

2, 1979-2001, 2002

\section{Modelling studies of wind field}

K. Radics et al.

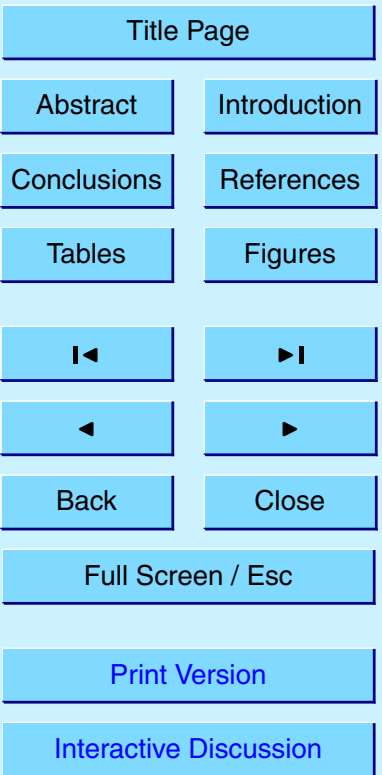

Fig. 2. Urban climate station at the Eötvös Loránd University (Budapest, Hungary) installed and maintained with the co-operation of the Hungarian Meteorological Service.

(C) EGU 2002 


\section{ACPD}

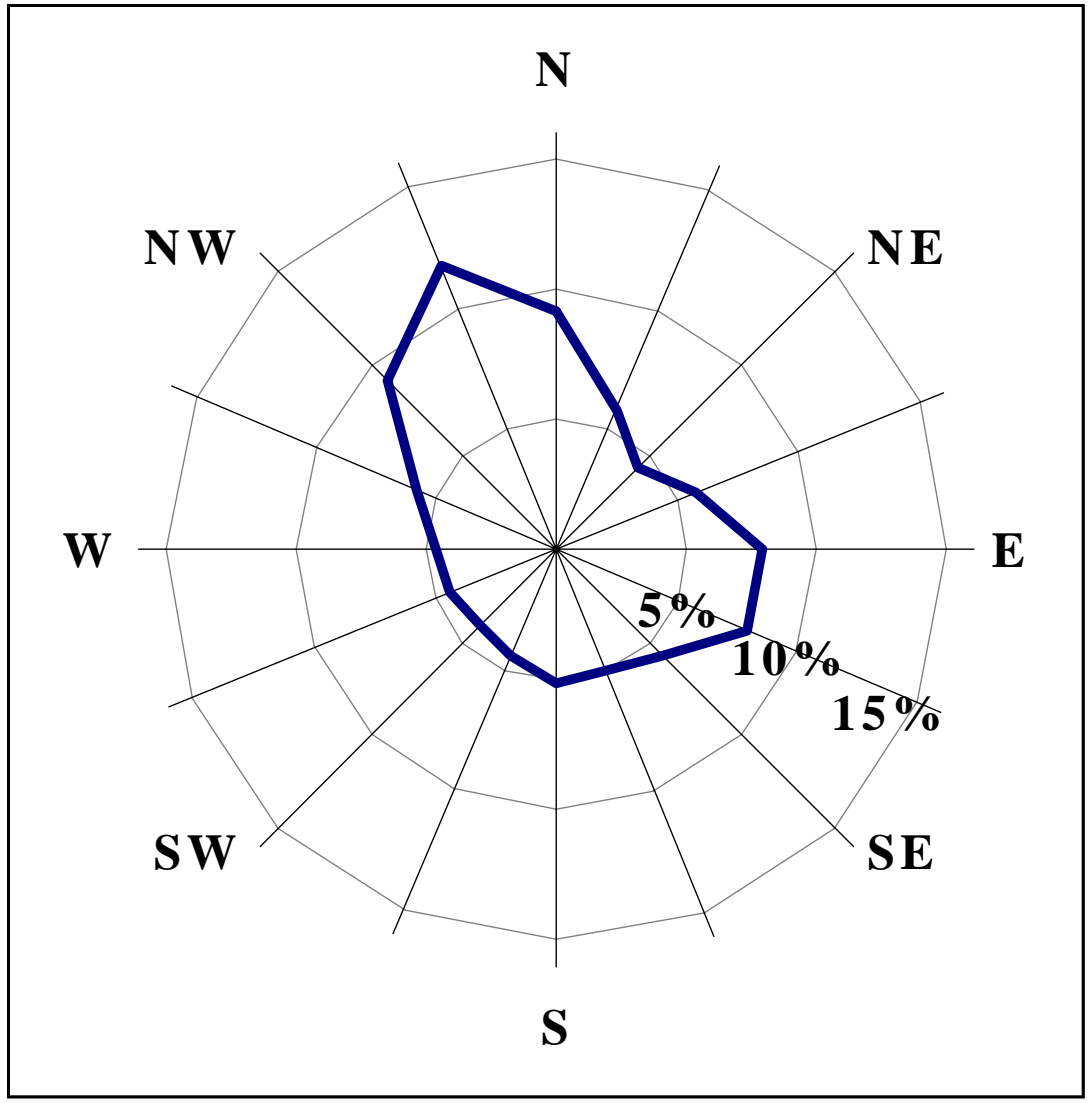

2, 1979-2001, 2002

\section{Modelling studies of} wind field

K. Radics et al.
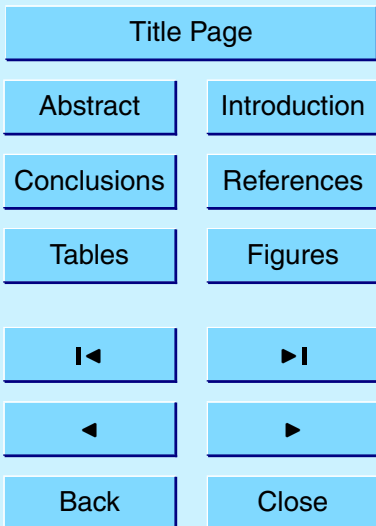

Full Screen / Esc

Print Version

Interactive Discussion

Fig. 3. Distribution of wind directions observed at $10 \mathrm{~m}$ height in Budapest based on 30-yearlong (1961-1990) time series (after HMS, 2002).

(C) EGU 2002 


\section{ACPD}

Modification of characteristical wind direction by orography and built-up areas in Budapest

2, 1979-2001, 2002

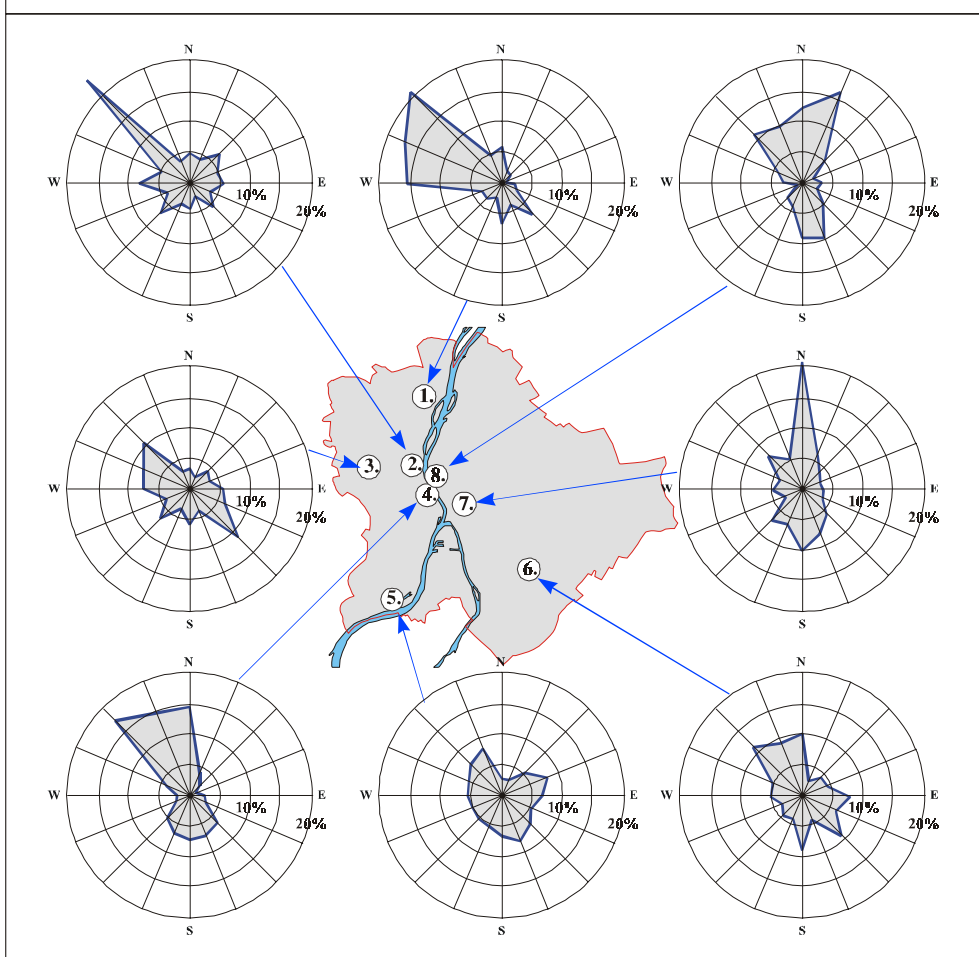

\section{Modelling studies of} wind field

K. Radics et al.

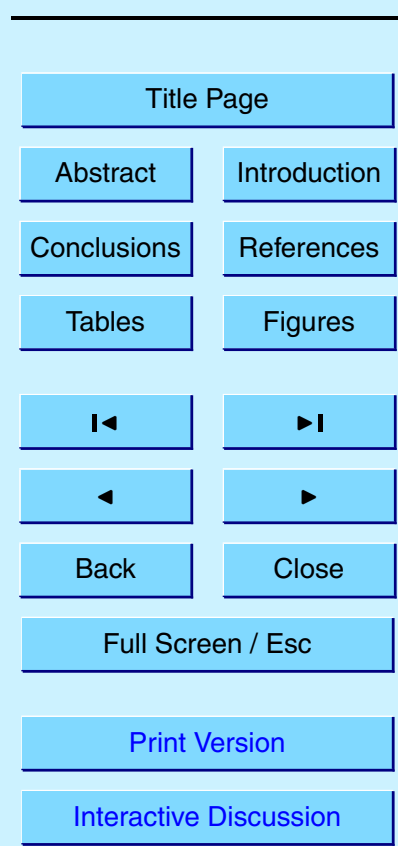

Fig. 4. Climatological relative frequency of the main wind directions observed at 8 measuring points at $10 \mathrm{~m}$ height in Budapest based on five-year-long data set. High variation can be found because of the large differences in elevation and built-up density. (Description of the stations is in Table 2.)

(C) EGU 2002 


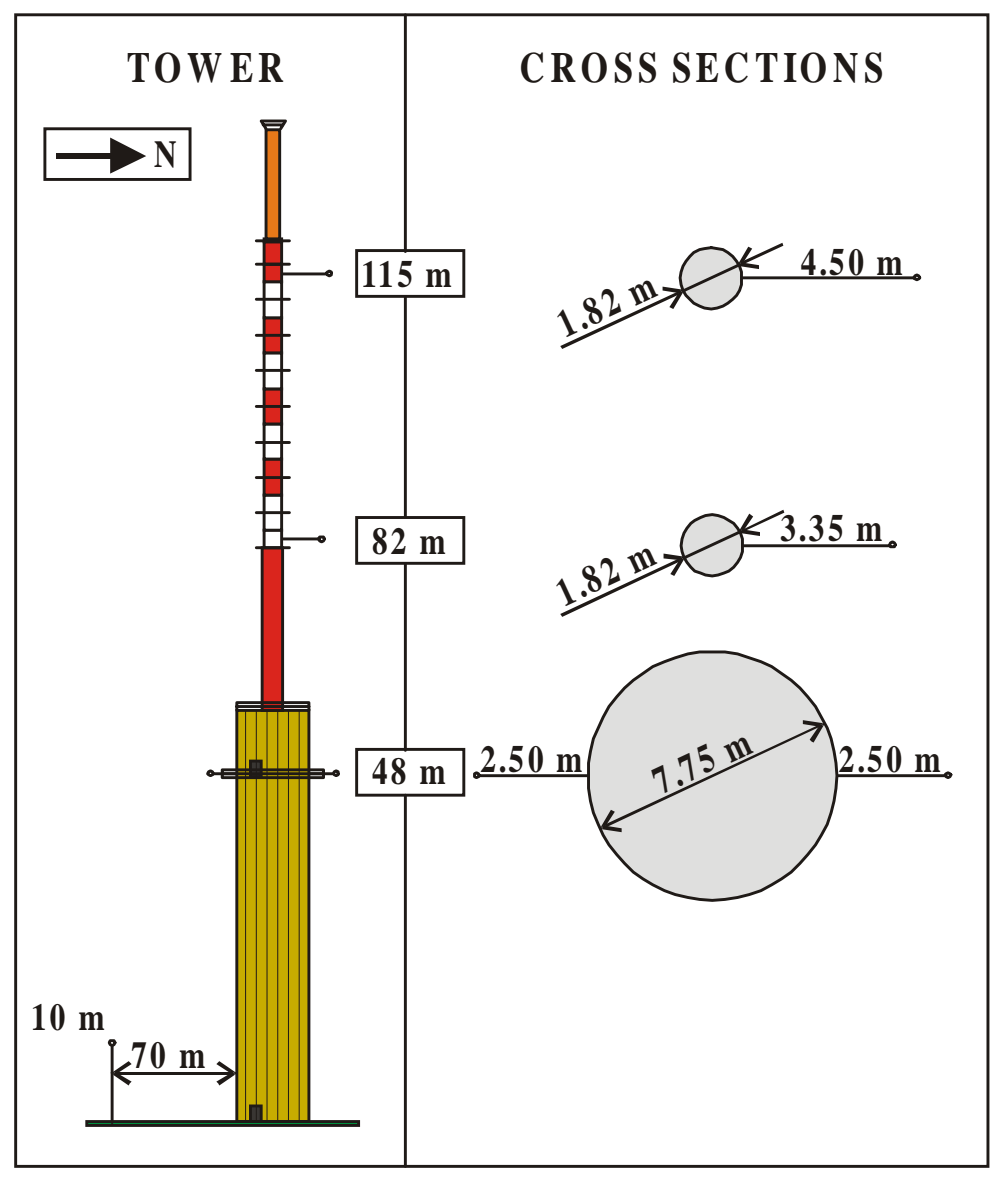

ACPD

2, 1979-2001, 2002

\section{Modelling studies of} wind field

K. Radics et al.
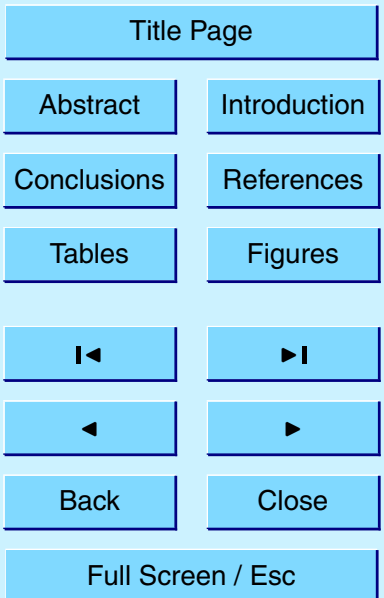

Print Version

Interactive Discussion

Fig. 5. Structure of the wind profile measuring station in Hegyhátsál.

(C) EGU 2002 


\section{ACPD}

2, 1979-2001, 2002

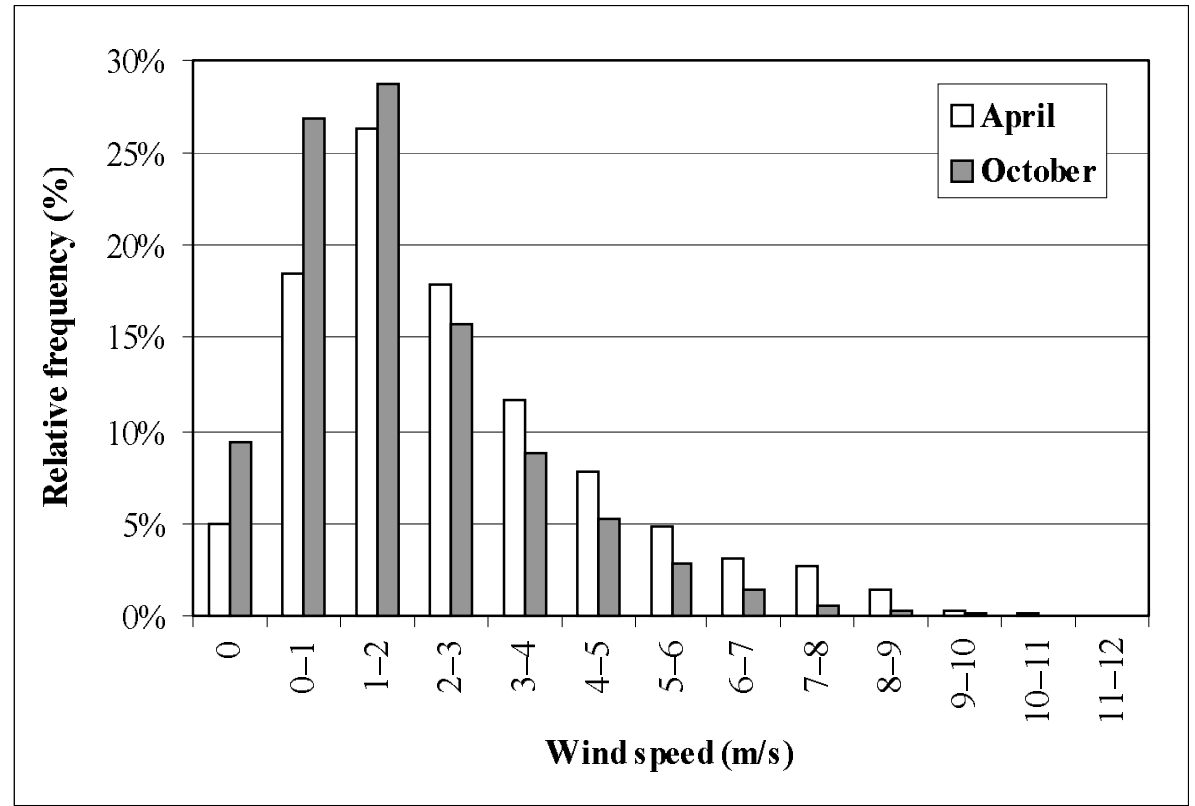

Modelling studies of wind field

K. Radics et al.

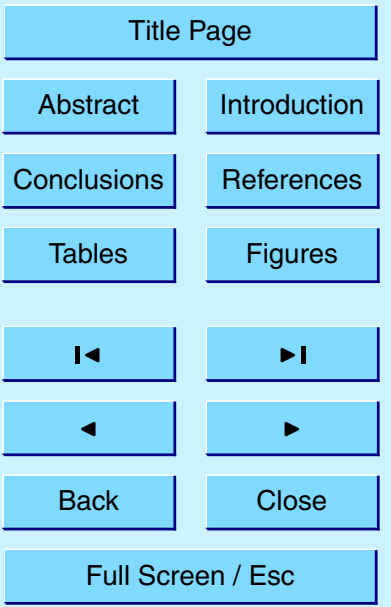

Fig. 6. Frequency distributions of wind speed measured at $10 \mathrm{~m}$ height in April and October at station Hegyhátsál (1995-2000).

Print Version

Interactive Discussion

(C) EGU 2002 


\section{ACPD}

2, 1979-2001, 2002
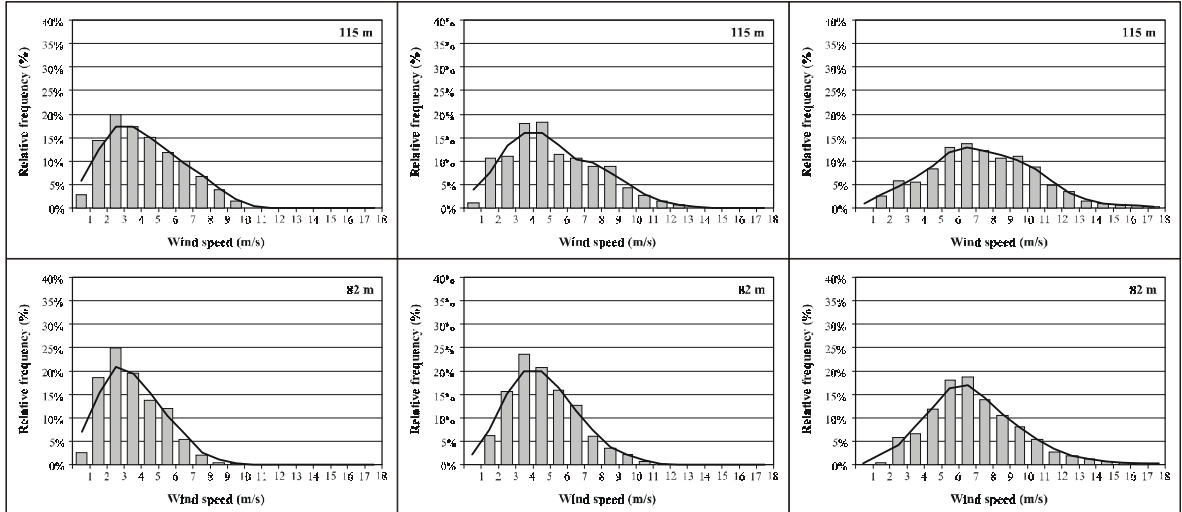

Wnd speed $(\mathrm{m} / \mathrm{s})$

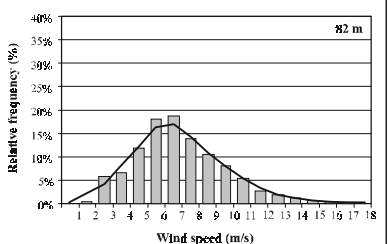

Wint speed $(\mathrm{m} / \mathrm{s})$

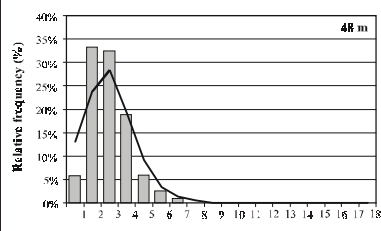

Wind speced ( $\mathrm{m} / \mathrm{s})$

Wind speed at $10 \mathrm{~m}: 1-2.5 \mathrm{~m} / \mathrm{s}$

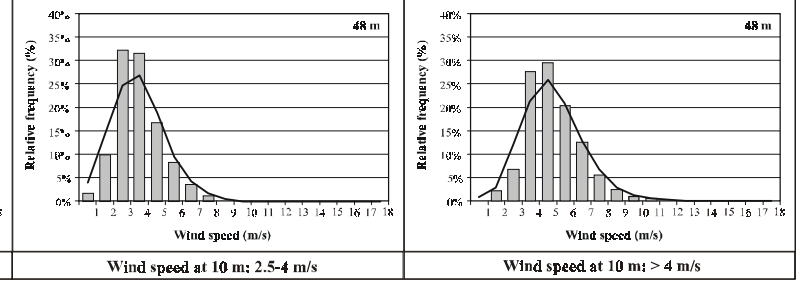

Fig. 7. Relative frequencies of wind speed observed at three tower levels in April (1995-2000) using the tercile classification of April near surface data. Smoothing is indicated by solid lines.

\section{Modelling studies of wind field}

K. Radics et al.

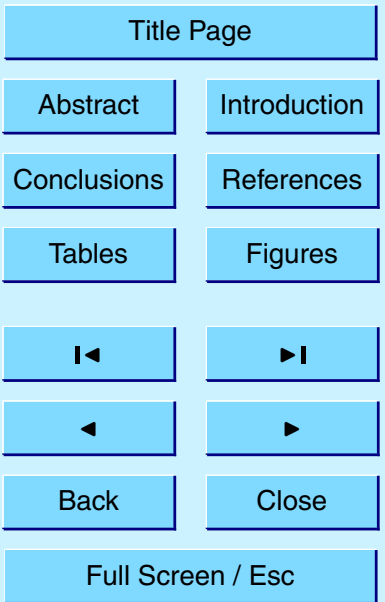

Print Version

Interactive Discussion

(C) EGU 2002 


\section{ACPD}

2, 1979-2001, 2002
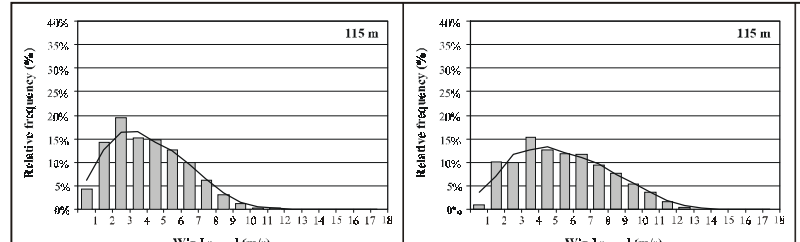

Wind speed $(m / s)$

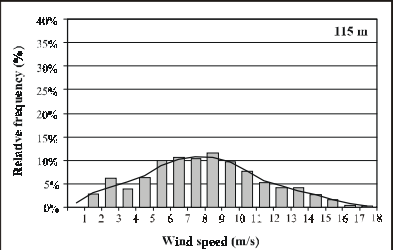
Wind speed (m/s)
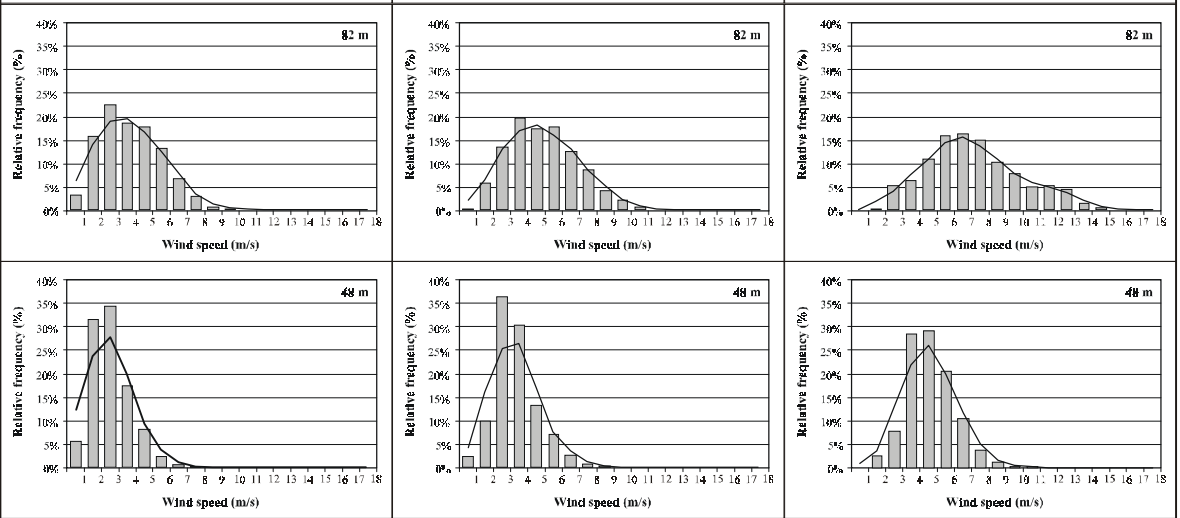

Wind speed at $10 \mathrm{~m}: 1-2.5 \mathrm{~m} / \mathrm{s}$

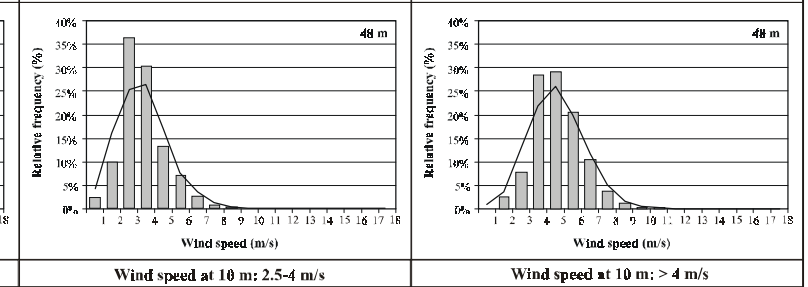

Fig. 8. Relative frequencies of wind speed observed at three tower levels in October (19952000) using the tercile classification of April near surface data. Smoothing is indicated by solid lines.

\section{Modelling studies of wind field}

K. Radics et al.

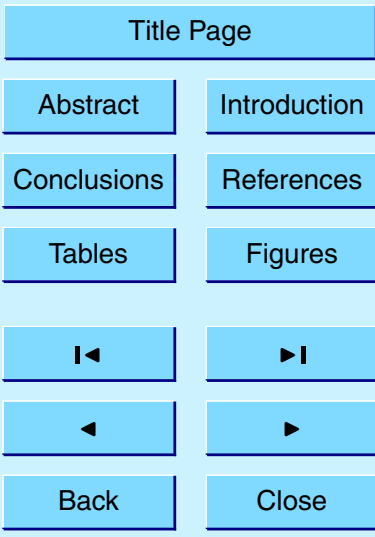

Full Screen / Esc

Print Version

Interactive Discussion

(C) EGU 2002 


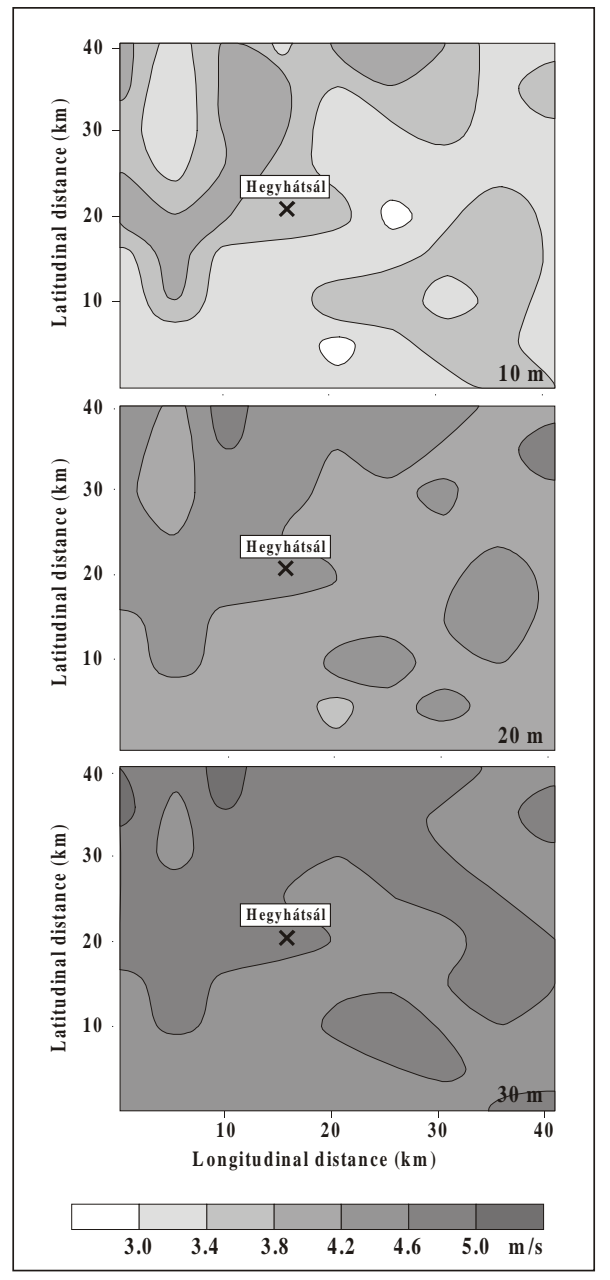

ACPD

2, 1979-2001, 2002

Modelling studies of wind field

K. Radics et al.

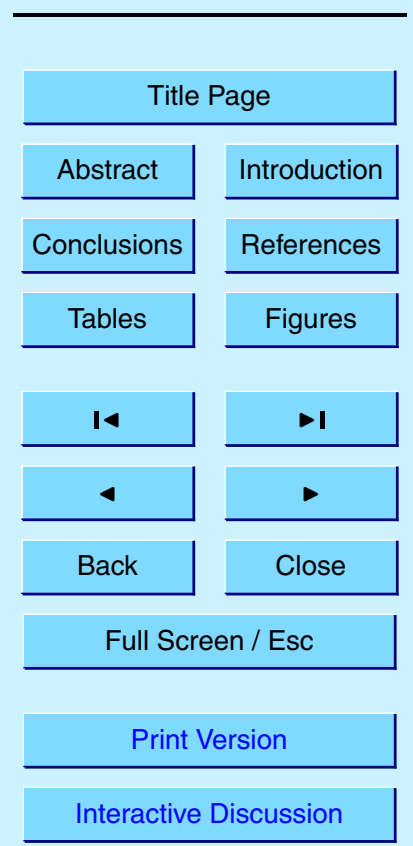

Fig. 9. Simulated average wind speed values at different levels around station Hegyhátsál.

(C) EGU 2002 


\section{ACPD}

2, 1979-2001, 2002

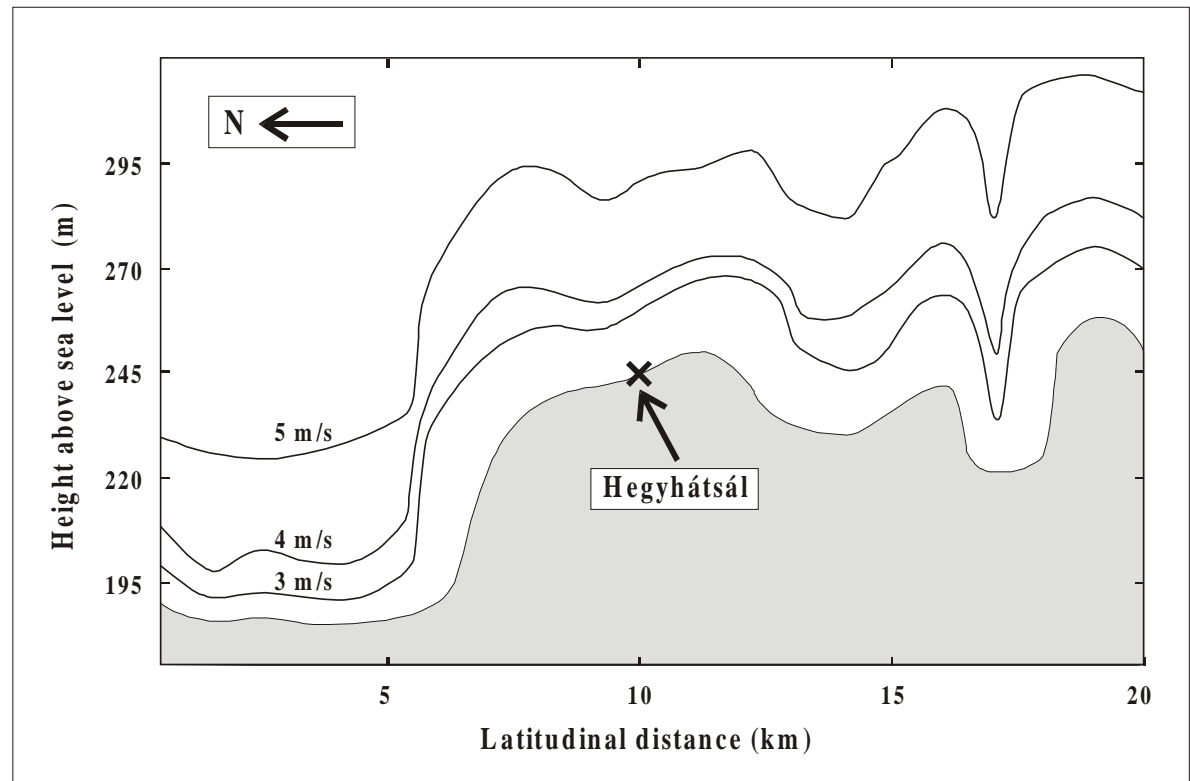

\section{Modelling studies of} wind field

K. Radics et al.

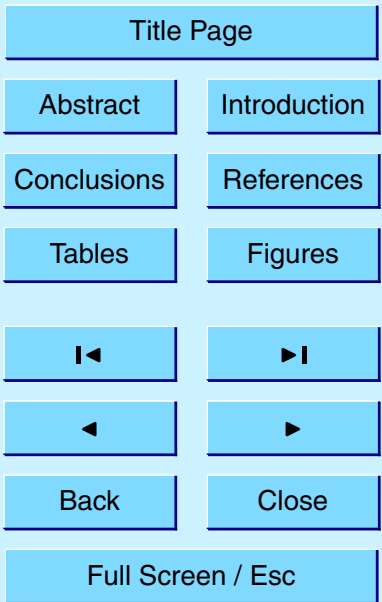

Fig. 10. Latitudinal (N-S) vertical cross-section of mean simulated flow demonstrating wind speed isolines around station Hegyhátsál.

Print Version

Interactive Discussion

(C) EGU 2002 


\section{ACPD}

2, 1979-2001, 2002

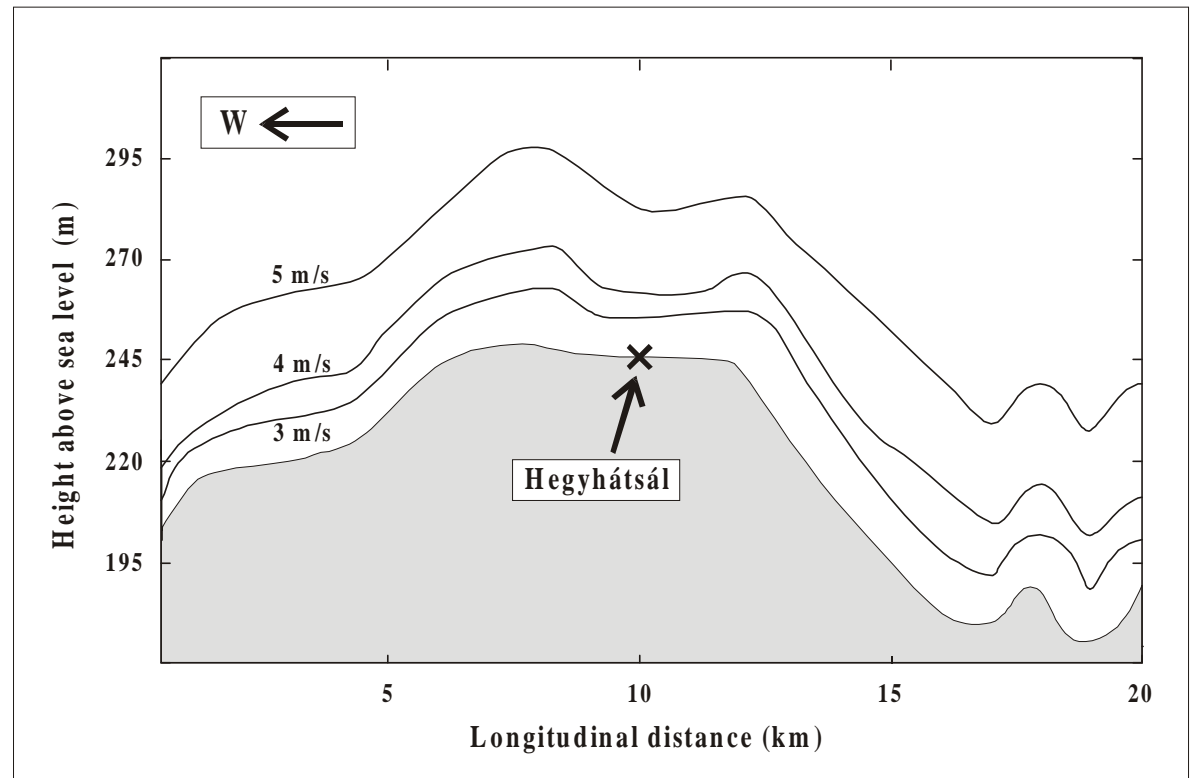

\section{Modelling studies of} wind field

K. Radics et al.

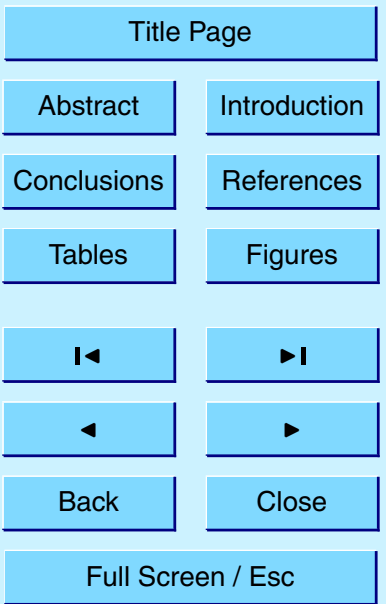

Fig. 11. Longitudinal (W-E) vertical cross-section of mean simulated flow demonstrating wind speed isolines around station Hegyhátsál.

Print Version

Interactive Discussion

(C) EGU 2002 